\title{
Determining the stability of slopes in the conditions of transport infrastructure objects construction
}

\author{
Zaven Ter-Martirosyan and Vitalii Sidorov ${ }^{*}$ \\ Moscow State University of Civil Engineering, Yaroslavskoe shosse, 26, Moscow, 129337, Russia
}

\begin{abstract}
The article is devoted to the stability determining of the slopes, near which are being carried out works on the construction of the foundation of an automobile overpass. The methods of determining the landslide pressure on the retaining structures, accounting for the technological vibration load on the base, which occurs when the sheet pile is submerged into soil base during the excavation are considered. The analysis of the options for usage the strength undrained characteristics of the soil base under vibration influence on them is made. The risk of construction works near the slope is estimated with the forecasting of the safety coefficients and limiting slip surfaces obtained by the finite element method implemented in the PLAXIS geotechnical software. Many factors of influence on the safety of the slope were taken into account: the staging of construction, the change in the hydrogeological situation, the application of technological and vibrational loads. Based on the results obtained, possible types of work to increase the stability of the slope are presented, and conclusions are drawn on the need for additional studies in the field of undrained properties in case of vibrational loads.
\end{abstract}

\section{Introduction}

Problems related to the stability of natural slopes do not lose their relevance at the present time, although they have been solved since old times both by traditional analytical and numerical methods. And the calculated cases are determined as a consideration of potentially landslide slopes both in the natural state and under the influence of external factors [1-2], as well as in the transformation of the original slope for various purposes. Such cases may include the construction near the edge or the bottom of the slope, involving the excavation of a soil massif or the formation of embankments, the application of loads on the base during the storage of materials, the application of dynamic or vibrational loads to the soil base when the structural elements are embedded. A significant impact on the stability of the slope is also provided by operating conditions of buildings that was constructed near the slope, for example for road infrastructure there are dynamic impacts from moving large-sized freight vehicles [3].

*Corresponding author: vitsid@ mail.ru 
The standard composition of the slope calculations includes an analysis of their natural state and the forecast of changes in their stability, taking into account many factors, such as changing the relief, changing the hydrogeological conditions, changing the conditions for the movement of surface waters, changing the physical and mechanical characteristics of the soils composing the slope, the effect of external loads and impacts, activation and development of landslide processes and erosion, the emergence of seismic influences, etc. [4].

In this paper, to determine the magnitude of the landslide pressure and the stability of the slope and the "slope-retaining structures" system, the finite element method implemented in the PLAXIS software was used. The peculiarities of the calculation cases are the provision of a complex effect on the initial state of the slope, consisting of the presence of unloading impacts at the level of the foot of the slope, the production of excavations of the soil massif for the foundation of the supports of the automobile overpass [5], and the vibration effects to the soil base when the metal sheet piles are embedded. Special attention is also paid to the strength characteristics of soils under conditions of vibration effects [6-7] and to the influence of undrained soil characteristics on the results obtained.

The article describes two cases of calculation by the finite element method related to slope stability in the process of road construction. The first case involves the process of determining the landslide pressure to the piles of the retaining structure in one of the sections. The second is devoted to determining the stability of a slope in the conditions of constructing the supports of an automobile overpass.

Table 1. Soil parameters

\begin{tabular}{|c|c|c|c|c|}
\hline No & Soil layer & $\begin{array}{l}\text { Internal } \\
\text { friction } \\
\text { angle, }\end{array}$ & $\begin{array}{c}\text { Cohesion, } \\
\mathrm{kPa}\end{array}$ & $\begin{array}{c}\text { Undrained } \\
\text { shear } \\
\text { strength, } \\
\mathrm{kPa}\end{array}$ \\
\hline 2 & stiff loam & 9 & 36 & 90 \\
\hline $2 a$ & sandy loam & 25 & 17 & 80 \\
\hline 3 & stiff clay & 11 & 92 & 70 \\
\hline 4 & stiff loam & 9 & 36 & 90 \\
\hline 5 & soft loam & 8 & 13 & 40 \\
\hline $5 \mathrm{a}$ & $\begin{array}{l}\text { soft sandy } \\
\text { loam }\end{array}$ & 25 & 17 & 80 \\
\hline 6 & stiff clay & 11 & 92 & 70 \\
\hline
\end{tabular}

Generally, 7 engineering-geological elements are allocated along the route of the road. No. 1a is anthropogenic sandy soil. No. $1 \mathrm{~b}$ is represented by technogenic clay soil. No. 2 is the cover loam. No. 3 is a landslide bedrock. No. 4 was a light and silty loam of a turgidlike consistency. Layer No. 5 was a light silty loam. A light semi-solid clay in the base of 
the slope was identified as a No. 6 layer. Subsequently, in some sections of the route, a more differentiated base separation system was introduced.

The construction situation was also complicated by the presence of three water horizons, one of which lay close to the surface of the relief.

\section{Methods}

The main objectives of the calculations were to predict the most dangerous sliding surface [8], formed in the massif of the landslide slope, and also to determine the magnitude of the landslide pressure on the piles of the containment structure.

To calculate the stability of the slope at various stages of construction, the finite element method was used as the most optimal method of calculation, which is able to take into account the presence of underground structures and the stage of work on the site. A quantitative indicator of the degree of slope stability is the safety factor (reliability), which is determined by the ratio of the initial and ultimate cohesion of the ground, or by the ratio of the tangents of the initial and limiting values of the angles of internal friction:

$$
K=\frac{c_{\text {init }}}{c_{\text {ult }}}=\frac{\operatorname{tg} \varphi_{\text {init }}}{\operatorname{tg} \varphi_{\text {ult }}}
$$

where $c_{\text {init }}, c_{\text {ult }}$ - initial and ultimate values of cohesion ;

$\varphi_{\text {init }}, \varphi_{\text {ult }}$ - initial and ultimate values of internal friction angle.

PLAXIS 2D 2018.0 [9], widely used in geotechnical practice, was used as a calculation complex for solving problems. This program carries out the forecast of the safety factor using the " $\varphi$-c reduction" method [10-11], which consists in the fact that in the calculation process the named strength characteristics of soils are gradually reduced, which continues until the moment of collapse of the slope. Thus, the program receives the limit values of these characteristics. After this, according to formula (1), the coefficient itself is found.

Calculation of landslide pressure was also carried out with the help of PLAXIS. The landslide pressure itself is defined as the force that is the difference between the holding and shearing forces (moments) acting along the slip surface in the soil massif of the slope. It is usually found as the difference between the resultant force of pressure on the holding structure from the upper part of the body of the alleged landslide and the resultant ground repelling below the structure. In the computational complex, it is possible to obtain pressure diagrams along the required section in the ground, and also directly on the contact "structure-soil massif".

Calculations on the first problem - the determination of the magnitude of landslide pressure on piles - were carried out in several stages. The first stage is the loading of the calculated array with the weight of the soil and the determination of its initial (natural) stress-strain state. The second stage is the calculation of the stability of the initial state of the slope. The third stage is the calculation of the stress-strain state and stability of the system after construction work on the slope flaking and the construction of the retaining structures.

The second and third calculations also included the step of immersing the sheet piling of the Larsen-5 elements, which was done by the method of vibration dumping. The operation of the ICE $32 \mathrm{RF}$ (nonresonant high-frequency vibrator) was simulated with the following parameters: 
Table 2. The vibrator ICE 32 RF parameters

\begin{tabular}{|c|c|c|c|}
\hline $\begin{array}{c}\text { Static } \\
\text { moment of } \\
\text { unbalances, } \\
\mathrm{kg} * \mathrm{~m}\end{array}$ & $\begin{array}{c}\text { Amplitude, } \\
\mathrm{mm}\end{array}$ & $\begin{array}{c}\text { Frequency, } \\
\mathrm{rpm}\end{array}$ & $\begin{array}{c}\text { Applied } \\
\text { load, } \mathrm{kH}\end{array}$ \\
\hline 32 & 9 & 36 & 90 \\
\hline
\end{tabular}

Short-term impact on the soil grounds of high-frequency loads leads to a specific case of the base, so water, located in the structure of the soil massif, does not have time to squeeze out of pores and this behaviour more corresponds to undrained behaviour. The parameters of undrained strength (minimum) are presented in Table 1. Since before the calculation it is not possible to determine the zone of influence of the vibrational action, the comparative calculations of the case of dynamic calculation with the use of parameters of undrained behaviour for both the entire soil massif and for the restricted area around immersed sheet piling.

\section{Results}

Figure 1 shows the results of calculating the stability of slope No1. From the resulting slip surface, it can be seen that the potential landslide occupies virtually the entire volume of the slope, but the safety factor is 1.238 , which indicates a sufficient overall stability of the system.

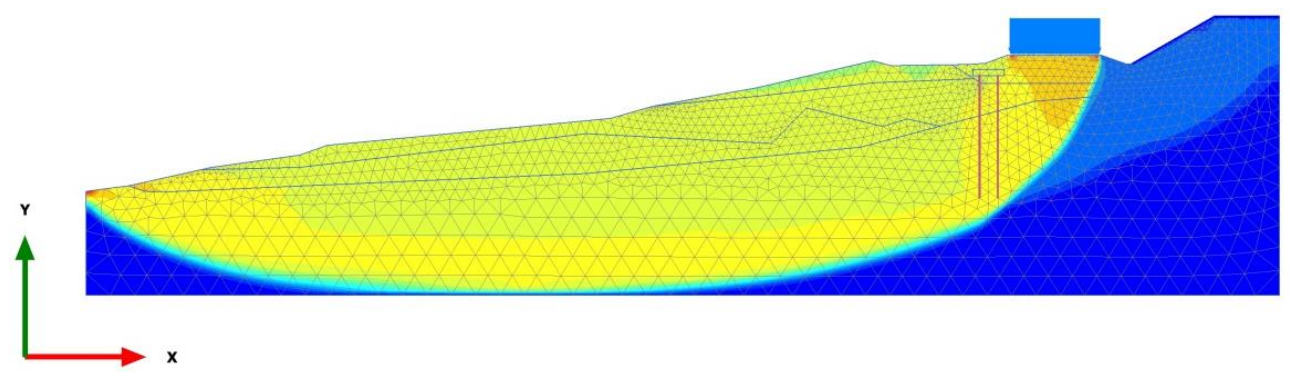

Fig. 1. A view of the potentially dangerous sliding surface of a landslide, $\mathrm{Ksf}=1.238$

Special tools of the PLAXIS program make it possible to obtain the form of a plot of landslide pressure distribution along the pile shaft, as well as internal forces in the piles that occur when bending takes place. The values of internal forces are within the permissible limits of the project and confirm the designed diameter for piles of $1.5 \mathrm{~m}$.

The greatest interest in the calculation of the second slope was caused by the immersion of the tongue (the effect of dynamic impact on the slope) with various soil properties, as well as the possibility of excavating the foundation pit under the trestle support in the immediate vicinity of its sole. Figure 3 shows a picture of the potential sliding surface of a soil massif after application of a dynamic load and using drained soil characteristics.

The results indicate that the slope is not sufficiently stable, and the dynamic highfrequency impact along with the removal of the part, the loading of the sole of the slope (old mound) reduced the safety factor from 1,061 to 1,022 .

When setting the ground undrawn properties for the entire volume of the slope, the picture looks quite different (Figure 4). The slope is unstable, and the slip surface captures the entire volume of the model. 

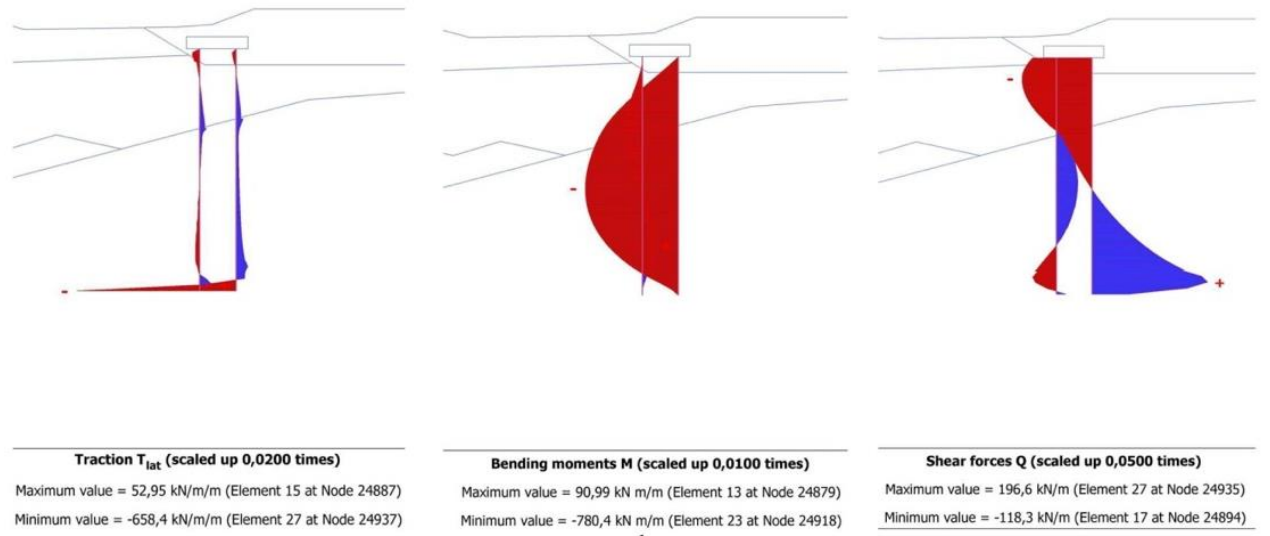

a
Bending moments $\mathrm{M}$ (scaled up 0,0100 times)

Maximum value $=90,99 \mathrm{kN} \mathrm{m} / \mathrm{m}$ (Element 13 at Node 24879)

Minimum value $=-780,4 \mathrm{kN} \mathrm{m} / \mathrm{m}$ (Element 23 at Node 24918)

Fig. 2. Plots of landslide pressure, bending moments and lateral forces in pile elements in case of displacement of a landslide

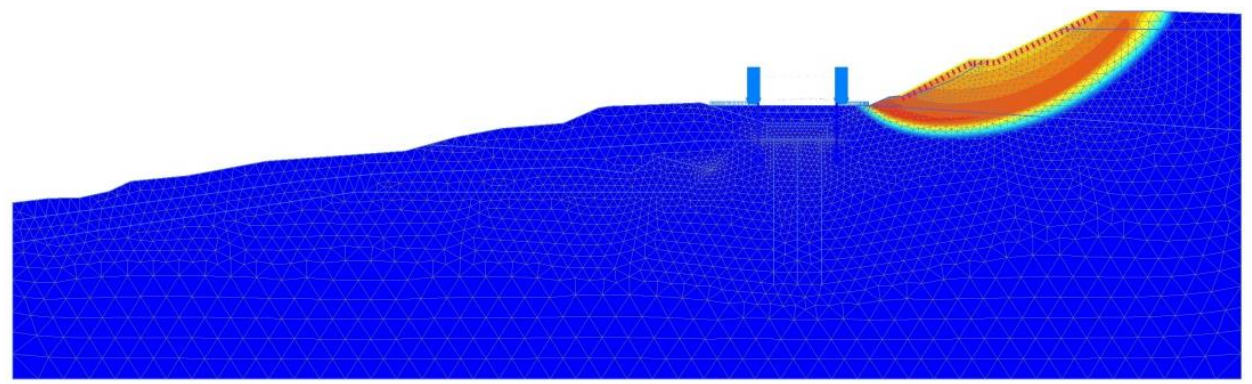

Fig. 3. Potentially dangerous sliding surface of a landslide after application of dynamic loads, Ksf = 1.022

When carrying out the calculation for setting undrained soil properties only in the zone of interaction with the tongue, a slip prism was obtained, completely repeating the one shown in Fig. 3, however, the safety factor was 1.044.

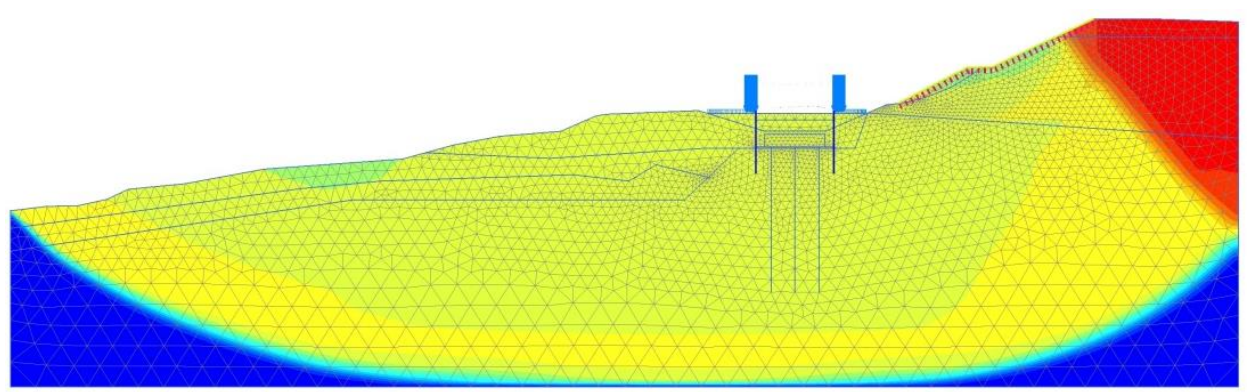

Fig. 4. Potentially dangerous sliding surface of a landslide after application of dynamic loads (undrained behaviour of the grooves as a whole, $\mathrm{Ksf}=0.95$

The last result of the calculation was the proof of the danger of construction work in the immediate vicinity of the foot of the slope. Figure 5 shows the deformed scheme (destruction) of the excavation in the simulation of its excavation to the bottom. 


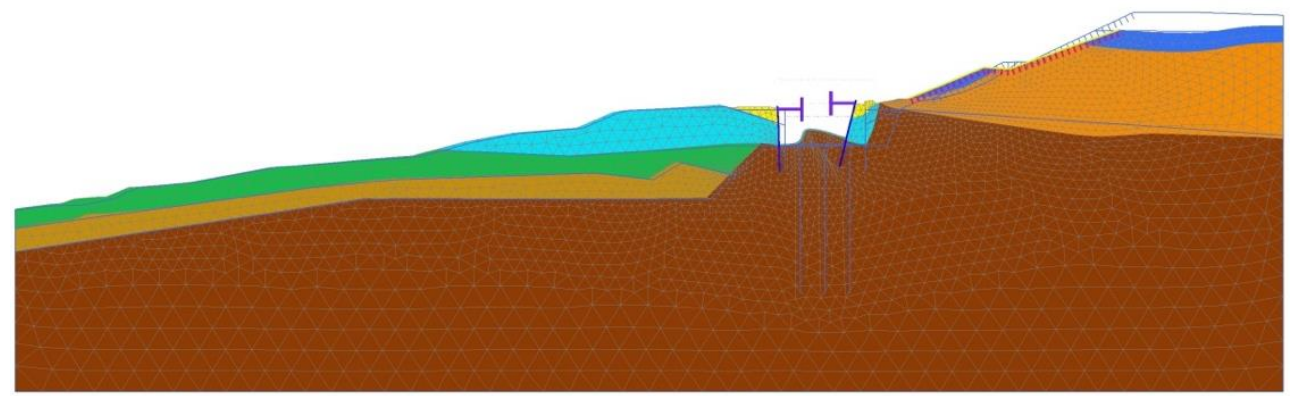

Fig. 5. Scheme of the deformed state after excavation to the bottom of the excavation (the scale of movements is increased by 10 times for clarity)

\section{Conclusions}

The determination of landslide pressure to the retaining structures is carried out within the framework of the theory of limiting equilibrium. To assess it using the graphic-analytical method, the cut-off method is used, in which the slope is divided into parts and the forces within this part are considered, as well as inter-section forces.

However, when determining landslide pressure by the finite element method, the estimator should be sure that its slope is in the state of limiting equilibrium [12], otherwise it is possible to obtain internal forces in structures corresponding to the resting pressure or small movements of the retaining structure. Therefore, it is necessary to make sure that during the modelling the upper part of the slope is unstable and really applies the greatest possible pressure on the structure. This can be achieved by additional calculation of the slope without a retaining structure, which must result in destruction and give a certain slip surface of the soil massif, which will subsequently be cut into pieces by the retaining structure.

Simulation of the construction of the automobile overpass foundation near the foot of the slope showed a great danger of destruction of the excavation and the insufficient rigidity of its enclosing structures and the depth of immersion. Vibration effects from sheet piles penetration affect negatively the overall safety factor of the system under consideration. Various options for the use of undrained soil base parameters are considered, but we consider it more correct to apply them directly to soils near the submerged sheet pile wall as being most exposed to these impacts.

Possible options to increase the stability of the slope are the following measures: flattening and terracing of the slope with a decrease in its steepness; a significant increase in the rigidity of the retaining structures of the excavation adjacent to the slope body, to ensure the perception of a possible additional landslide pressure without loss of stability of the excavation; increasing the stability of the slope by using pile structures (single-row or multi-row) [13-14].

A promising direction of the development of the topic is the development of a method for forecasting the refined zone of influence of construction works near the slope for assigning to these soils undrained properties or another behaviour model, since their deformations undergo significant changes in comparison with the surrounding ground, which does not receive perturbations from vibration.

This work was financially supported by the Ministry of Education and Science (state task \#1.4984.2017/6.7). All tests were carried out using research equipment of The Head Regional Shared Research Facilities of the Moscow State University of Civil Engineering. 


\section{References}

1. S.E. Cho Prediction of shallow landslide by surficial stability analysis considering rainfall infiltration. Eng. geol. 231, 126-138 (2017)

2. M.E. D'Effremo, A. Sciotti Numerical analyses of the effects induced by the tunnel excavation in a slope. Gallerie e grandi opera sotterranee. 124, 31-38 (2017)

3. S.I. Macij, E.V. Bezuglova, Upravlenie opolznevym riskom (Landslide risk management) (AlVI-design, Krasnodar, 2010)

4. S.I. Macij, Protivoopolznevaya zashchita (Anti-landslide protection) (AlVI-design, Krasnodar, 2010)

5. S.I. Macij, D.V. Leyer Issledovanie vzaimodejstviya opolznevogo grunta s zashchitnymiyo sooruzheniyami opor ehstakad (Investigation of the interaction of landslide soil with the protected structures of overpass supports). Stroitel'stvo i arhitektura (Construction and architecture). 1, 49-53 (2013)

6. C.B. Qin, S.C. Chian, J. Yu, Stability analyses of initial collapse and earthquakeinduced secondary failure using discretization-based kinematic analysis. Inter. J. of geomech. 18, No11, 04018155 (2018)

7. X. Zhang, S.W. Sloan, E. Onate Dynamic modelling of retrogressive landslides with emphasis on the role of clay sensitivity. Intern. J. for num. and anal. meth. in geomech. 42, No15, 1806-1822 (2018)

8. W. Gao Investigating the critical slip surface of soil slope based on an improved black hole algorithm. Soils and found. 57, No6, 988-1001 (2017)

9. R.B.J. Brinkgreve, E. Engin, W.M. Swolfs PLAXIS 2D 2010 user manual (Plaxis bv., Deft, 2010)

10. R. Afiri, S. Gabi Finite element slope stability analysis of Souk Tleta dam by shear strength reduction technique. Innov. infrastr. solutions 3, No1, 6 (2018)

11. A.P. Dyson, A. Tolooiyan Optimisation of strength reduction finite element method codes for slope stability analysis. Innov. infrastr. solutions 3, No1, 38 (2018)

12. Y.M. Cheng, N. Li Equivalence between bering-capacity, lateral earth-pressure, and slope-stability problems by slip-line and extremum limit equilibrium methods Intern. J. of geomech 17, No12, 04017113 (2017)

13. S.I. Macij, F.P. Derevenec Primenenie konechnyh ehlementov dlya issledovaniya vzaimodejstviya gruntov opolznya so svayami (The use of finite elements to study the interaction of soil landslides with piles). Osnovaniya, fundamenty i mekhanika gruntov (Bases, foundations and soil mechanics) 4, 8-12 (2005)

14. A.K. Ryabuhin, S.I. Macij, E.V. Bezuglova Issledovanie diapazona dopustimyh gorizontal'nyh peremeshchenij buronabivnyh svaj protivoopolznevyh sooruzhenij (Investigation of the range of permissible horizontal displacements of bored piles of landslide structures). Vestnik volgogradskogo gosudarstvennogo arhitekturnostroitel'nogo universiteta. Seriya: Stroitel'stvo i Arhitektura (Bull. of the Volgograd State Arch. and Constr. Univ. Series: Building and Arch.) 31-2(50), 279-283 (2013) 